\title{
Physicochemical characteristics and antioxidant activities of new Asian pear cultivars
}

\author{
Gui-Hun Jiang $^{1} \cdot$ Sun-Hee Yim $^{2} \cdot$ Jong-Bang Eun ${ }^{1}$ \\ 신품종 배의 물리화학적 특성 및 항산화 활성
}

강귀훈 ${ }^{1} \cdot$ 임순희 ${ }^{2} \cdot$ 은종방 ${ }^{1}$

Received: 27 June 2016 / Accepted: 2 September 2016 / Published Online: 31 December 2016

(C) The Korean Society for Applied Biological Chemistry 2016

\begin{abstract}
The Asian pear (Pyrus pyrifolia Nakai) has historically been one of the most popular fruits in Korea because of its sweetness and juiciness. Nowadays, $81.5 \%$ pears of the 'Niitaka' cultivar are grown in Korea, and most of these are consumed as table fruits. Due to the increase in consumer demand for novel Asian pear varieties, developing new cultivars is of great commercial interest. Since 1984, 'Niitaka' cultivar has been introduced in Korea and $13.3 \%$ was developed into new cultivars in the last 20 years alone. Recently, the consumption rate of fresh Asian pears has been limited. The demand for pears, especially the 'Niitaka' cultivar has no longer increased. As a result, new cultivars of Asian pears have been introduced and their properties have been investigated. This review article provides an overview of the physicochemical characteristics and antioxidant activities of new cultivars of Asian pears.
\end{abstract}

Keywords Antioxidant activities - Asian pear - New cultivar · Physicochemical characteristics

Jong-Bang Eun $(\triangle)$

E-mail: jbeun@chonnam.ac.kr; jongbang@hotmail.com

${ }^{1}$ Department of Food Science and Technology, Chonnam National University, Gwangju 61186, Republic of Korea

${ }^{2}$ Pear Research Station, National Institute of Horticultural and Herbal Science, Naju 58216, Republic of Korea

This is an Open Access article distributed under the terms of the Creative Commons Attribution Non-Commercial License (http://creativecommons. org/licenses/by-nc/3.0/) which permits unrestricted non-commercial use, distribution, and reproduction in any medium, provided the original work is properly cited.

\section{서 론}

배는 배나무과속(Pyrus)에 속하는 낙엽고목 식물의 열매로서 예 로부터 우리나라에서 즐겨먹는 과실 중의 하나이다. 배의 종류 에는 3 가지가 대표적인데 그 중에서 우리나라와 일본이 원산지 인 남방형 동양배 (Pyrus pyrifolia Nakai)와 중국이 원산지인 북방형 동양배(Pyrus ussuriensis Maxim), 그리고 유럽 및 서아 시아가 원산지인 서양배(Pyrus communis Linn) 가 있다(Lee 등, 1983). 고 품질의 배의 과실은 육질이 연하고 과즙이 풍부할 뿐 만 아니라 당도가 높고 향기 및 씹히는 맛 등 품질이 뛰어난 특성이 있다(Harada 등, 2005).

배는 수분이 다량 함유되어 있고, 그 외의 성분은 탄수화물 이 주를 이루며 단맛을 내는 가용성 고형분 함량은 10-13\% 정도로 품종에 따라 다르다(Lee 등, 2003). 유리당 함량의 경우, 감미를 나타내는 sucrose, fructose 및 glucose가 주 성분이다 (Choi 등, 1998; Jiang 2015). 단백질과 지질은 매우 적은 편이 고, 식이섬유 함량은 가식부 $100 \mathrm{~g}$ 당 $1 \sim 2 \mathrm{~g}$ 정도로 다른 과실 과 비교했을 때 비교적 높은 편으로 다이어트에 도움 주고 장 내 유해균 생성을 억제하는 정장작용을 하는 것으로 알려져 있 으며(RDA 2003; Son 등, 2004), 이러한 배에는 칼슘, 마그네 슘, 인, 나트륨 등이 많이 함유 되어 있다(Yu 1989) 배의 효능 으로는 예로부터 한방에서 기침, 가래, 천식, 해열, 숙취, 이뇨, 변비 치료에 상용되어져 왔고(Lee 등, 1975), 배의 과육과 과피 등에는 페놀계 성분인 chlorogenic acid, arbutin, (+)-chtechin 등 기능성 성분(Zhang 등, 2003; Zhang 2007; Choi 2009; Ahn 2012; Seo 2014)과 당질 중 하나인 펙틴 물질의 주요 급 원이다(Zhang 2007). 또한 동양배의 저장기간에 따른 폴리페놀 화합물의 함량 및 성분변화와 항산화 효과에서 과육보다는 과 피에 많은 양이 존재하였다(Zhang 등, 2003). 특히 한국산 배 와 서양배의 이화학적 특성을 비교할 때 한국산 배는 서양 배 보다 총당, 칼륨 및 수분함량이 높은 반면 서양 배는 식이섬유 
및 탄수화물 함량이 한국산 배보다 비교적 높았다(Lee 등, 2012).

우리나라에는 1906년 일본에서 개량된 품종들이 도입되어 전 국적으로 재배되고 있으며 배의 재배 품종으로는 '신고', '원 황', ‘장십량', ‘황금배', ‘감천배', ‘추황배', ‘화산' 등이 있는데 국내에서의 배 재배는 신고 품종이 주로 생산되어 오고 있다가 새로운 배 품종이 육성되어 보급되기 시작하면서 전체 재배 면 적의 $13.3 \%$ 를 신품종이 차지하고 있다. 그 후 배 품종에 대 한 연구가 다양하게 실시되어 오면서, 최근 소비자들이 신품종 등 다양한 품종의 배에 대한 요구가 커지고 있는 실정이다(농 촌진흥청, 배 산업동향 자료). 이러한 문제점을 해결하기 위해 서 국내에서는 다양한 수확기를 가진 신품종 배의 재배가 대안 으로 제시되고 있으며, 최근 신 육성 품종은 기존의 품종들에 비해 당도가 높고 육즙이 연하여 품질 면에서 우수한 특성을 가지고 있다(Kang 등, 2011). 따라서 지금까지 연구되었던 신품 종 배들의 품질 특성 및 기능성을 조사하여 관련 논문들을 종 합적으로 정리하기 위해 이에 대한 전반적인 문헌 고찰이 필요 하다고 생각되어 본 총설에서는 신품종 배들의 물리적, 화학적 특성 및 이의 항산화 활성에 대해서 고찰하고자 한다.

\section{신품종 배의 품종}

'화산'은 1981년에 ‘풍수'와 '만삼길'을 교배하여 1994년 최종 선발된 품종으로 숙기는 10 월 상순으로서 '신고' 보다 7 10일 정도 빠르다(Kim 등, 1994). '한아름' 배는 국립원예특작과학원 에서 1988년 '신고'에 ‘추황'을 교배하여 지역적응성시험을 거 쳐 선발된 조생종 품종으로 숙기는 수원지방 기준으로 8월 중 순이다(Kim 2002). '원황'은 '조생적'에 '만삼길'을 교배하여 1994년 최종 선발되었고, 9월 초에 수확이 가능한 조생종 품종 이다(Kim 등, 1995). 껍질째 먹는 배로 육성한 ‘조이스킨'은 1994년 '황금배'에 ‘조생적'을 교배하여 2006년부터 2011년까지 10 개 지역에서 지역적응성을 평가하였고, 품질의 우수성이 인정 되어 껍질째 먹는 전용 품종으로 최종 선발하였다(Kang 등, 2012). '만풍배'는 ‘풍수'에 '만삼길'을 교배하여 1997년에 최종 선발되었으며 숙기가 신고보다 1주일 정도 빠르고 과실이 크고 품질이 우수하여 '신고'를 일부 대체할 품종으로 주목받고 있다 (Cho 등, 2003). '만수'는 '단배'에 '만삼길'을 교배하였으며 극 대과, 극 만생종 품종으로 품질이 우수하다(Kim 등, 2001).

\section{신품종 배의 일반적인 특성}

배는 우리나라의 중요한 과수 작물로서 포도, 사과, 감귤 다음 으로 과수 농가의 중요한 소득원이 되고 있다. 현재 우리나라 배의 국내 생산량은 2000년부터 2013년까지 약 282,212 톤을 유지하고 있으며, 또한 배의 소비는 주로 생식용으로 제한되어
있고 그 수요는 증가하지 않고 있는 실정이다. 현재 국내에서 주로 재배되고 있는 배 품종은 1906년에 일본에서 도입된 '신 고'(Pyrus pyrifolia cv. Niitaka)가 재배 면적의 $80 \%$ 이상을 차지하고 있으며, 1984년 부터 국내에서 새로운 배 품종이 육 성되어 보급되기 시작하여 2007년 까지 20여 년에 걸쳐 전체 재배 면적의 $13.3 \%$ 를 신품종으로 갱신되어 오고 있다. 그 뒤 배 품종에 대한 연구가 거듭되면서 최근 들어, 소비자들의 기 호도에 발맞추어 신품종 배들이 육성 보급되어 있고, 이에 관 한 품질특성에 관한 연구가 많이 이루어지고 있다.

Table 1은 배 신품종의 일반적인 품질특성을 나타낸 것이다. $\mathrm{Kim}$ 등(2015)의 연구 보고에 의하면, 수확한 '원황' 품종의 과 중은 $535 \mathrm{~g}$, 경도는 $27.7 \mathrm{~N}$, 가용성 고형분 함량은 $12.9{ }^{\circ} \mathrm{Brix}$, 적정산도는 $0.250 \%$ 및 2.0 의 전분지수를 함유하고 있다. '신고' 에 비해 감미가 높은 ‘원황’배는 유통 중 생리장해의 발생이나 품질하락 속도가 다른 품종에 비해 빠른 편이다(Hong 등, 2004). 따라서 과심 흑변 현상이나 경도 감소가 많이 발생하는 데, Lee 등(2012)은 '원황' 배를 수확 후에 $1.0 \mathrm{ppm}$ 의 1-MCP 처리로 과실의 경도를 2 배 이상 증가시켰다고 보고하였다. 반 면에 '만풍배'는 $925 \mathrm{~g}$ 의 과중, $29.1 \mathrm{~N}$ 의 경도, $13.5{ }^{\circ} \mathrm{Brix}$ 의 가용성 고형분 함량, $0.123 \%$ 적정산도 및 1.5 의 전분지수를 나타내었다. Park 등(2013)의 연구 결과에 의하면 '만풍배'의 가 용성 고형분 함량은 만개 후 초기에는 낮은 함량으로 유지되다 가 성숙기인 161 일에는 $13.0{ }^{\circ} \mathrm{Brix}$ 까지 증가하였다고 하였다. '만 풍배'의 가용성 고형분 함량은 ‘원황' 또는 ‘화산’의 초기 생장 과는 다른 유형의 패턴을 나타내었으며, 성숙기의 가용성 고형 분 함량은 '원황'과 비슷하였다(Chun과 Lee 2011). 또한 Chun 과 Lee (2011)에 의하면 산 함량에 있어서는 만개 후 49일에 가장 높았으나 그 후 서서히 낮아지는 것으로 보아 생육이 진 전될수록 당산비가 높아지는 것으로 관찰되어 '원황’과 비슷한 경향을 나타내었다고 하였다. Park 등(2013)의 보고에 의하면 ‘ 만풍배'의 단맛은 과실의 크기가 클수록 단맛이 높을 것으로 추 정하고 있는데, 이는 사과나 배의 과실의 크기 또는 과피색 등 의 외관 품질인자들은 내부 품질 인자에 의한 영향을 받기 때 문이라고 하였다(Kingston 1991). Kang 등(2014)은 '한아름'과 '조이스킨'의 품질 특성을 측정한 결과, '한아름'의 과중은 $398 \mathrm{~g}$, 경도 $2.9 \mathrm{~N}$, 가용성 고형분 함량 $12.6{ }^{\circ} \mathrm{Brix}$, 적정산도 $0.08 \%$ 를 함유되어 있다고 하였다. 또한, '조이스킨' 품종의 과실 특 성으로는 과중이 $235 \mathrm{~g}$, 가용성고형분 함량은 $14.9{ }^{\circ} \mathrm{Brix}$ 으로 매 우 높은 당 함량을 나타내었고, 과육의 경도는 $2.56 \mathrm{~N}$ 및 적정 산도는 $0.239 \%$ 를 나타내었다고 보고하였다. 반면에 대조구인 '신고'의 무게는 $566 \mathrm{~g}$ 가용성 고형분 함량은 $12.22{ }^{\circ} \mathrm{Brix}$, 경도 는 $0.96 \mathrm{~N}$ 및 적정산도는 $0.100 \%$ 라고 보고하였다(Lee 등, 2003). 위의 연구 결과를 볼 때, 꼬마배라고 불리는 '조이스킨'

Table 1 Quality characteristics of new cultivars of Asian pears from Korea

\begin{tabular}{lcccccc}
\hline Cultivars & Weight $(\mathrm{g})$ & $\begin{array}{c}\text { Soluble solid content } \\
\left({ }^{\circ} \text { Brix }\right)\end{array}$ & $\begin{array}{c}\text { Firmness } \\
(\mathrm{N})\end{array}$ & $\begin{array}{c}\text { Starch index } \\
\text { Titratable acidity } \\
(\%)\end{array}$ & References \\
\hline Wonhwang & 535 & 12.90 & 27.7 & 2.0 & 0.250 & Kim et al. (2015) \\
Manpungbae & 925 & 13.50 & 29.1 & 1.5 & 0.123 & \\
Hanareum & 398 & 12.60 & 2.9 & 0.0 & 0.080 & Kang et al. (2014) \\
Joyskin & 250 & 14.90 & 2.56 & - & 0.239 & Lee et al. (2003) \\
Niitaka & 566 & 12.22 & 0.96 & - & 0.100 & \\
\hline
\end{tabular}


Table 2 Free sugar content of new cultivars of Asian pears from Korea (Unit: mg/100 g)

\begin{tabular}{|c|c|c|c|c|c|c|c|c|c|c|c|}
\hline \multirow{2}{*}{ Cultivars } & \multicolumn{10}{|c|}{ Free sugar content } & \multirow{2}{*}{ References } \\
\hline & Sucrose & Fructose & Galactose & Glucose & Sorbitol & Maltose & Rhamnose & Ribose & Mannose & Xylose & \\
\hline Yeongsan & 150.5 & 1907.1 & 24.256 & 576.626 & - & 0.316 & 1.016 & 0.061 & 3.611 & 5.431 & \\
\hline Mansu & 465.5 & 1521.7 & 18.711 & 336.587 & - & 0.207 & 0.828 & 0.188 & 1.069 & 6.488 & Jiang (2015) \\
\hline Sinhwa & 302.3 & 1331.7 & 21.124 & 638 & - & 0.299 & 0.025 & 0.069 & 1.308 & 3.834 & \\
\hline Wonhwang & 6140 & 2900 & - & 890 & 1660 & - & - & - & - & - & Kim et al. (2015) \\
\hline Joyskin & 6320 & 4390 & - & 2120 & 1870 & - & - & - & - & - & Kang et al. (2014) \\
\hline Niitaka & 3100 & 2030 & - & 2.020 & - & - & - & - & - & - & Choi et al. (1972) \\
\hline
\end{tabular}

Table 3 Organic acid content of new cultivars of Asian pears from Korea (Unit: mg/100 g)

\begin{tabular}{lcccc}
\hline \multirow{2}{*}{ Cultivars } & \multicolumn{2}{c}{ Organic acid content } \\
\cline { 2 - 4 } & Malic acid & Citric acid & Tartaric acid & Shikimic acid \\
\hline Wonhwang & 1768 & 622 & 83.8 & - \\
Manpungbae & 1174 & 483 & 64.0 & - \\
Niitaka & 2430 & 690 & - & Kim et al. (25) \\
\hline
\end{tabular}

Table 4 Amino acid content of new cultivars of Asian pears from Korea (Unit: mg/100 g)

\begin{tabular}{|c|c|c|c|c|c|c|c|c|c|c|c|}
\hline \multirow[b]{2}{*}{ Cultivars } & \multicolumn{10}{|c|}{ Amino acid content } & \multirow[b]{2}{*}{ References } \\
\hline & Urea & $\begin{array}{c}\text { Asparagin } \\
\mathrm{e}\end{array}$ & $\begin{array}{l}\text { Aspartic } \\
\text { acid }\end{array}$ & Taurine & $\begin{array}{l}\text { Glutamic } \\
\text { acid }\end{array}$ & Serine & Threonine & Histidine & Valine & Argine & \\
\hline Wonhwang & 752 & 196 & 100 & 19 & 14 & - & - & - & - & - & \multirow{2}{*}{ Kim et al. (2015) } \\
\hline Manpungbae & 388 & 88 & 59 & 15 & 9 & - & - & - & - & - & \\
\hline Niitaka & - & - & 91.20 & - & 16.14 & 44.75 & 38.12 & 36.53 & 13.36 & 14.65 & Choi et al. (1972) \\
\hline
\end{tabular}

은 매우 높은 가용성 고형분 함량임을 확인할 수 있었으며, 만 풍배’의 과중이 다른 품종보다 비교적 크고 당산비도 높으며, ‘원황'배는 감미가 우수하여 유통면에서 문제점이 있어, 이의 문 제점을 해결하기 위해 많은 연구들이 활발히 진행되고 있다고 한다. 또한 Jiang (2015)은 '신화', '만수', '영산' 품종의 이화학 적 특성을 조사하였는데, '신화'와 '영산'의 $\mathrm{pH}$ 값은 5.68 과 5.48 로 '신고'(Lee 등, 2003)보다 높게 측정되었고, 가용성 고형분 함량은 '신고'가 '감천배'(NIHHS 2011)와 유사한 값을 나타냈 다고 보고하였다. 또한 '신화', '만수', '영산'의 비타민 C 함량 은 '신고'(Park 등, 1988)보다 조금 높게 측정되었고, 미네랄 함 량을 측정한 결과 칼슘, 칼륨, 마그네슘, 염 및 인이 주요 구성 성분이었고 그 중에서 칼륨 함량이 $105-130 \mathrm{mg} / 100 \mathrm{~g}$ 으로 제일 많이 검출되었다고 보고하였다.

\section{신품종 배의 유기산, 유리당 및 아미노산 성분}

신품종의 유기산과 유리당 및 아미노산 구성 성분 및 함량을 Table 2, 3 및 4에 나타내었다. '원황' 및 '만풍배'의 유기산은 malic acid, citric acid 및 tartaric acid가 검출 되었으며, ‘원황' 이 '만풍배' 보다 높은 유기산 함량을 나타내었다. 과일에 함유 된 과육의 산은 $0.2 \%$ 내외로서 malic acid와 citric acid가 주 요한 산이다. 그 외 succinic acid, fumaric acid, oxalic acid, tartaric acid와 maleic acid가 함유되어 있으며(Lee 등, 1972), 과실 중의 malic acid는 과실의 성숙에 따라 급격히 감소하고 citric acid는 유과기로부터 성숙기까지 함량의 변화가 거의 없 다(Hong 등, 1998). 또한 유기산은 당과 함께 단맛에 영항을 주는 당 산비는 과실의 품질을 결정하는 주요한 요소이다 $(\mathrm{Kim}$
등, 1997). 신품종 배의 아미노산 구성은 urea, aspargine, aspartic acid, taurine 및 glutamic acid로써 ‘원황'이 ‘만풍배'보 다 아미노산 함량이 높게 나타났다(Kim 등, 2015). 배의 유리 아미노산은 $150 \mathrm{mg} / 100 \mathrm{~g}$ 내외로 그 함량이 과실류에서 중간 정 도의 함량을 나타낸다. Choi 등(1998)은 '신고'와 '영산'배의 주된 유리아미노산 중 aspartic acid의 함량이 가장 높았고 다음 은 serine, threonine, histidine, glutamic acid, valine, argine, alanine 순으로 높았으며 총 유리아미노산 함량은 배의 성숙에 따라 함량이 점점 증가하는 경향을 나타내었다고 하였다. 또한 유리당 함량에 있어서, ‘원황' 품종의 유리당은 sucrose, glucose, fructose 및 sorbitol로 구성되어 있으며, 미숙과에서는 fructose와 sorbitol이 주요 당이었으나 적숙과에서는 sucrose만이 주요 당이었다. 수확 한 '만풍배'의 주요 유리당 성분으로는 ‘원 황'과 마찬가지로 sucrose, glucose, fructose 및 sorbitol이 검출 되었는데 그 중에서 fructose 함량이 가장 높았고(Kim 등, 2015), ‘조이스킨' 품종도 sucrose, glucose, fructose 및 sorbitol 등 4개의 주요 유리당이 측정되었다(Kang 등, 2014). 그러나 Jiang (2015)의 연구에 의하면 '만수'와 '신화' 품종을 HPLC로 유리당을 분석한 결과 위 논문과 조금 다르게 검출되었는데, sucrose, fructose, galactose와 glucose 등 4가지 당이 높은 함 량으로 측정되었고, maltose, rhamnose, ribose, mannose와 xylose는 미량으로 검출되었다. 또한 이 연구에서 sucrose와 fructose의 함량은 '만수' 품종이 '신화' 보다 더 높게 측정되었 다고 보고하였다. 당 조성은 품종에 따라 다르지만 일반적으로 장미과의 과실에서는 잎으로부터 과실에의 당분의 이행은 sorbitol의 형태로 진행하고 과실의 비대에 수반하여 fructose와 
Table 5 Total phenolics content and total flavonoids content of cultivars of Asian pears from Korea (Unit: mg/100 g)

\begin{tabular}{|c|c|c|c|c|c|c|c|c|c|c|c|c|c|}
\hline \multirow[b]{2}{*}{ Cultivars } & \multicolumn{6}{|c|}{ Total phenolics } & \multicolumn{6}{|c|}{ Total flavonoids } & \multirow[b]{2}{*}{ References } \\
\hline & $\begin{array}{l}\text { Whole } \\
\text { fruit }\end{array}$ & Peel & Fresh & Core & $\begin{array}{l}\text { Young } \\
\text { fruit }\end{array}$ & $\begin{array}{l}\text { Mature } \\
\text { fruit }\end{array}$ & $\begin{array}{l}\text { Whole } \\
\text { fruit }\end{array}$ & Peel & Fresh & Core & $\begin{array}{l}\text { Young } \\
\text { fruit }\end{array}$ & $\begin{array}{l}\text { Mature } \\
\text { fruit }\end{array}$ & \\
\hline Wonwhang & - & 723.6 & 112.5 & 357 & - & - & - & 125.2 & 25.9 & 49.5 & - & - & \\
\hline Pungsu & - & 699.3 & 51.5 & 254 & - & - & - & 135.7 & 30.1 & 45.1 & - & - & \\
\hline Whangkeumbae & - & 748.4 & 106.0 & 296.4 & - & - & - & 141.4 & 32.5 & 58.5 & - & - & Choi et al. (2006) \\
\hline Whasan & - & 760.3 & 77.0 & 371.9 & - & - & - & 139.8 & 34.1 & 54.8 & - & - & \\
\hline Niitaka & - & 800.6 & 89.9 & 401.5 & - & - & - & 164.2 & 38.9 & 60.0 & - & - & \\
\hline Wonwhang & - & 528 & 184 & - & - & - & - & 125 & 26 & - & - & - & \\
\hline Sunwhang & - & 531 & 181 & - & - & - & - & 127 & 23 & - & - & - & \\
\hline Whangkeumbae & - & 525 & 188 & - & - & - & - & 122 & 25 & - & - & - & Jin and Song (2012) \\
\hline Chuwhangbae & - & 520 & 186 & - & - & - & - & 117 & 21 & - & - & - & \\
\hline Niitaka & - & 534 & 189 & - & - & - & - & 124 & 26 & - & - & - & \\
\hline Gamcheonbae & 134 & 198 & 109 & 182 & - & - & 30.2 & 33.9 & 28.7 & 30.2 & - & - & \\
\hline Manpungbae & 116 & 179 & 97 & 185 & - & - & 25 & 29.2 & 24.3 & 26.9 & - & - & \\
\hline Chuwhangbae & 145 & 235 & 102 & 190 & - & - & 37.7 & 40.2 & 34.3 & 38.8 & - & - & Choi et al (2013) \\
\hline Hanareum & 145 & 222 & 113 & 229 & - & - & 29.2 & 31.9 & 28.4 & 30.9 & - & - & \\
\hline Niitaka & 121 & 178 & 95 & 177 & - & - & 26.8 & 29.4 & 24.9 & 27.2 & - & - & \\
\hline Wonwhang & - & 97.4 & 31.4 & 79.1 & 126.2 & 71.2 & - & 22.9 & 9.1 & 19.0 & 30.3 & 19.1 & \\
\hline Whangkeumbae & - & 84.9 & 34.8 & 84.7 & 138.0 & 65.6 & - & 22.3 & 9.9 & 19.1 & 33.1 & 19.1 & Park et al (2012) \\
\hline Chuwhangbae & - & 104.2 & 35.7 & 68.4 & 188.6 & 70.2 & - & 25.3 & 10.7 & 18.7 & 36.5 & 20.4 & \\
\hline
\end{tabular}

glucose가 축적되고 비대 후 sucrose가 급격히 축적되어 감미를 보완한다. 따라서 배 과실의 성숙과정 중 감미를 나타내는 가 용성 당은 fructose, glucose 및 sucrose 등 당과 당 알콜인 sorbitol이다(Hong 등, 1998). 또한 총 당 함량은 품종에 따라 $1-3 \%$ 의 차이가 있고 생장과정 중 급속히 증가하며, 그 시기적 변화 패턴은 과실 생장 특히 과중의 증가 패턴과 거의 일치하 다고 하였다(Park 등, 1984).

\section{신품종 배의 총 폴리페놀 함량 및 플라보노이드 함량}

현재까지 신품종 배의 기능성 성분에 관한 연구들이 몇몇 보고 되고 있는데, 주로 총 폴리페놀과 플라보노이드 함량 분석은 Table 4에 측정되었다. 총 폴리페놀 함량에 있어서, Park 등 (2012)의 논문에 따르면 '추황배', ‘원황' 및 ‘황금배'를 $80 \%$ 에탄올로 추출하여 동결 건조한 후 총 폴리페놀 함량을 측정한 결과, 품종별로 유과기가 수확기보다 약 1.5 2.5배 높은 함량을 나타내었고. 수확기가 유과기보다 모두 낮게 검출되었다. 또한 수확기 부위별 총 폴리페놀 함량은 ‘원황'의 과피, 과심, 과육 이 97.4, 79.1, 31.4 mg/100 g으로 '황금배'와 ‘추황배' 보다 높 은 값을 나타낸 것으로 보고되었다. Choi 등(2013)에 연구에 의 하면, 품종별 '추황배'와 '한아름', '감천배' 의 총 폴리페놀 함 량은 '신고'와 '만풍배' 보다 높았다. 과피, 과육, 과심의 부위 별 총 폴리페놀 함량은 Park 등(2012)이 보고한 '원황', ‘황금 배', ‘추황배' 보다 높았지만 Zhang 등(2007)이 보고한 '추황배 '와는 비슷한 함량을 보였다. 또한 Choi 등(2006)의 울산에서 생산되는 배의 품종별 부위에 따른 생리활성 연구에서 조사한 ‘원황', ‘풍수', '황금배', '화산', '신고' 5품종의 총 폴리페놀 함 량보다 약간 낮게 나타냈다고 보고하였다. 또한, Jin과 Song (2012)은 배 품종 및 부위별 항산화 활성 논문에서 ‘원황', '선 황', ‘황금배', ‘추황배', ‘신고'의 총 폴리페놀은 '선황'과 ‘추황 배'가 가장 높게 측정되었다고 하였다.
총 플라보노이드 함량 연구들을 보면, 총 플라보노이드 함량 은 ‘추황배'에 있어 유과기 과실은 다른 두 품종보다 함량이 많 았다는 Park 등(2012) 보고가 있다. 수확기 과실의 총 플라보노 이드 함량이 과피는 유의적으로 '추황배'가 함량이 많았고, 과 육에서는 '추황배'가 함량이 제일 많았다. Choi 등(2006)의 연 구에서, 품종에 따른 부위별 총 플라보노이드 함량은 품종별로 '추황배'가 모든 부위에서 유의적으로 높은 함량을 나타내었다. 과피의 총 플라보노이드 함량은 '만풍배'가 $29.4 \mathrm{mg} / 100 \mathrm{~g}$ 으로 가장 낮았고, 과심의 함량에서는 '신고'가 가장 적었다. 과육은 '한아름', '만풍배', '신고'가 가장 낮게 나타냈다. Jin과 Song (2012)은 배 품종 및 부위별 항산화 활성 논문에서 '원황', '선 황', ‘황금배', ‘추황배', ‘신고'의 총 플라보노이드 함량을 측정 한 결과 5 품종에서 비슷한 함량을 나타냈으며, '신고' 품종에서 다소 낮은 함량을 보였다. 이와 같이 배의 유과기와 성숙기의 총 폴리페놀 함량과 총 플라보노이드 함량의 차이는 과실이 비 대함에 따라 과실내의 폴리페놀이 다른 물질과 결합하여 폴리 페놀과는 형태가 다른 물질로 과실 내에 축적되거나(Wilkinson 1970), 또 한 과실 비대 속도가 상대적으로 빨라 과피 또는 과 육의 페놀물질이 희석되었기 때문인 것으로 생각된다 $(\mathrm{Kim}$ 1988). Ryugo (1969)는 정색반응으로 배의 탄닌과 폴리페놀이 석세포가 가장 많이 함유된 도관속, 과심부 그리고 표피층에 많 이 분포되어 있다는 것을 검증하였고 Machida (1965)는 배의 과육 세포중에는 폴리페놀 성분을 함유하는 세포와 함유하지 않 는 세포가 있는데 폴리페놀을 함유하는 세포는 거의가 과피 부 분에 분포되어 있다고 하였다. 따라서 과피 중 총 폴리페놀 또 는 총 플라보노이드 함량이 과육이나 과심부위에 비해 높게 나 타낸 것으로 사료된다. 각 품종별 함량 차이에 있어서는, 시료 의 전처리; 신선한 과일, 동결건조, 추출용매의 사용 또는 배 생 산 지역이나 재배 조건에 따른 차이점이라고 생각된다. 
Table 6 Antioxidant activities of new cultivars of Asian pear

\begin{tabular}{|c|c|c|}
\hline Cultivars & Antioxidant activities & References \\
\hline Niitaka & $\begin{array}{l}\text { DPPH radical-scavenging activity, } \mathrm{ABTS}^{+} \text {scavenging activity, Nitrate radical- } \\
\text { scavenging activity, Reducing power, Xanthine oxidase, Electron donating ability }\end{array}$ & $\begin{array}{l}\text { Jin and Song (2012); Park et al. (2012); } \\
\text { Choi et al. (2013) }\end{array}$ \\
\hline Chuhwangbae & $\begin{array}{l}\text { DPPH radical-scavenging activity, } \mathrm{ABTS}^{+} \text {scavenging activity, Nitrate radical- } \\
\text { scavenging activity }\end{array}$ & $\begin{array}{l}\text { Park et al. (2012); Choi et al. (2013); } \\
\text { Jin and Song (2012) }\end{array}$ \\
\hline Mansu & $\mathrm{ABTS}^{+}$scavenging activity, Anti-oxidation & Lee et al. (2008) \\
\hline Sinhwa & $\begin{array}{l}\text { DPPH radical-scavenging activity, Reducing power, Nitrate radical-scavenging } \\
\text { activity }\end{array}$ & Jiang et al. (2016) \\
\hline Wonhwang & $\begin{array}{l}\text { DPPH radical-scavenging activity, } \mathrm{ABTS}^{+} \text {scavenging activity, Xanthine oxidase, } \\
\text { Nitrate radical-scavenging activity }\end{array}$ & $\begin{array}{l}\text { Park et al. (2012); Choi et al. (2006); } \\
\text { Jin and Song (2012) }\end{array}$ \\
\hline Manpungbae & DPPH radical-scavenging activity, Nitrate radical-scavenging activity & Choi et al. (2013) \\
\hline Kamcheonbae & DPPH radical-scavenging activity, Nitrate radical-scavenging activity & Choi et al. (2013) \\
\hline Hanareum & DPPH radical-scavenging activity, Nitrate radical-scavenging activity & Choi et al. (2013) \\
\hline Whasan & $\begin{array}{l}\text { ABTS }^{+} \text {scavenging activity, Electron donating ability, Nitrate radical-scavenging } \\
\text { activity, Xanthine oxidase }\end{array}$ & Choi et al. (2006) \\
\hline
\end{tabular}

\section{신품종 배의 항산화활성}

배의 항산화 활성에 대한 연구들도 많았지만, 신품종 배의 항 산화 활성에 대한 보고들도 다수 있었다. Table 5는 신품종 배 의 항산화활성을 나타낸 것이다. Park 등(2012)의 보고에 의하 면, '추황배', ‘원황' 및 '황금배' 등 3 개의 신품종 과실의 유과 기와 수확기별 DPPH radical 소거능을 조사한 결과, 3품종 모 두 유과기의 DPPH radical 소거능이 수확기보다 약 2 3배 정 도 우수하였으며 품종 간에는 유과기에 '추황배'가 $62.7 \%$ 로 다른 품종보다 높았다. 수확기 과실 부위별 DPPH radical 소거 능은 과피에서 과심과 과육보다 높게 나타났는데, 품종간에 따 른 부위별 DPPH radical 소거능은 과피에서는 '추황배'가 28.0 $\%$ 로 가장 높았으며 과심과 과육은 ‘황금배’에서 높았다. 또한 $\mathrm{ABTS}$ 양이온 소거활성에 있어서는 세 품종 모두 유과기가 수 확기보다 뚜렷하게 높은 $\mathrm{ABTS}$ 양이온 소거활성을 보였으며 유 과기와 수확기에서 '추황배'가 다른 두 품종 보다 높은 활성을 나타냈다. 수확시기에 과실 부위에 따른 $\mathrm{ABTS}$ 양이온 소거활 성을 조사한 결과, 세 품종 모두 과피, 과심, 과육 순으로 소거 활성이 높게 나타났으며 과피에서는 '추황배' 과심과 과육은 ‘황 금배'가 더 높아 DPPH radical 소거능과 유사한 결과를 나타내 었다. Jiang 등(2016)은 '신화'배 주스의 DPPH radical 소거능, 환원력 및 아질산염 소거능을 측정한 결과, 각각 $66.67,0.72$ 및 $11 \%$ 의 소거능을 나타냈다고 보고하였다. Choi 등(2013)의 연 구에서 4개의 신품종('감천배', '만풍배', ‘추황배', ‘한아름')과 '신고'의 DPPH radical 소거능 측정 결과, 품종별로는 추황배와 감천배가 높게 측정되었고, 아질산염 소거능은 '추황배'와 '한아 름’이 18.0, $17.9 \%$ 로 가장 높았으며, 부위별로는 과피에서 '감 천배'와 ‘추황배'에서 소거능이 우수하였다.

Jin과 Song (2012)은 한국 배 5 품종('원황', '선황', '황금배', '추황배', '신고')의 DPPH와 아질산염 radical 소거능을 측정한 결과, DPPH radical 소거능은 에탄올 용매 추출보다 메탄올 용 매 추출에서 높은 함량을 나타내었으며, 품종별로는 '황금배'와 ‘추황배'에서 좀 더 높은 소거능을 나타냈다. Lee 등(2008)이 과 실 부위별 총 폴리페놀과 총 플라보노이드 함량 및 $\mathrm{ABTS}$ 앙 이온을 조사한 결과 과피에서는 '만수' 품종보다 '신고' 품종에
서 총 폴리페놀 및 플라보노이드 함량이 많고 따라서 $\mathrm{ABTS}$ 앙 이온도 높았다. 위 논문들을 분석해 보면 DPPH radical 소거능, 아질산염 소거능, $\mathrm{ABTS}$ 양이온 소거활성 등은 총 폴리페놀 플 라보노이드의 변화량에 많이 의존하는 것으로 보아 밀접한 관 계가 있는 것으로 판단된다.

Choi 등(2006)의 보고에 의하면, 전자공여능은 과피가 과육과 과심보다 높은 활성을 보였으며, ‘화산’이 모든 부위에서 낮은 활성을, '황금배'가 비교적 높은 활성을 보였다. 아질산 소거작 용에 있어서는 '신고'의 과피와 과육이 $1 \%$ 추출물 농도에서 소거능이 아주 낮게 나타내었고, 각 품종 및 부위별 시료 추출 물 농도를 각각 조제하여 $\mathrm{HPLC}$ 를 이용하여 분석한 결과 각 추 출물의 xanthine oxidase 저해 활성은 배 추출물의 농도 증가에 따라 저해 활성이 증가함을 보였다. 그리고 과피와 과육의 경 우 추출물 농도 $1-10 \mathrm{mg} / \mathrm{mL}$ 처리 시 '풍수'와 '신고'가 높은 저해율을 보였고, 과심의 경우 추출물 농도 $10 \mathrm{mg} / \mathrm{mL}$ 처리 시 ‘원황'과 '신고'가 비교적 높은 저해율을 나타내었다.

\section{결 과}

배는 우리나라에서 널리 소비되고 있는 과일 중 하나로 알려져 있다. 그 중 '신고' 배의 생산량이 국내 배 생산량의 약 $80 \%$ 이상을 차지하여 단일 품종의 편중화로 인한 문제가 발생되고 있는 실정이며 이에 따른 소비자들의 수요를 대응하기 위해 신 품종 배의 재배면적을 늘리고 있다. 이러한 신품종 배의 품질 특성들을 알아보기 위해 신품종 배의 물리화학적 및 항산화활 성에 대한 보고들을 정리하여 총설로 제시하였다. 신품종 배는 '신고'와 비교 시 과실의 특성 면에서 매우 유사하였으나 과중 은 '만풍배'가 다른 품종보다 컸고 가용성고형분 함량은 껍질째 로 먹는 ‘조이스킨'이 월등히 높았다. 신품종 배의 주요 유리당 성분으로는 sucrose, fructose, galactose, sorbitol 및 glucose 등 이 검출되었다. 총 폴리페놀 함량, 총 플라보노이드 함량 및 항 산화활성은 배의 품종, 수확시기 및 부위에 따라 그 함량이 서 로 달랐다. 수확시기별로 조사한 결과 모든 신품종 배에서 유 
과기에 수확기보다 높은 총 폴리페놀과 총 플라보노이드가 검 출되었고 부위별로 조사한 결과 모든 신품종 배의 과피가 과육 보다 총 폴리페놀 함량과 총 플라보노이드 함량이 월등하였으 며 품종 간에는 유의적인 차이가 나타났다. 따라서 총 폴리페 놀과 총 플라보노이드 함량이 높으면 $\mathrm{DPPH}$ 라디칼 소거능, 아 질산염 소거능, $\mathrm{ABTS}$ 양이온 등 항산화활성이 증가하는 양상 을 보여주어 아주 밀접한 관계를 가지고 있는 것으로 나타났다. 그럼에도 불구하고 아직도 신품종 배의 물리화학적 특성이나 다 양한 생리활성 및 효능에 관한 보고는 아직 미약한 실정이어서 앞으로 이에 대한 연구가 더 많이 필요하다고 사료된다.

\section{초 록}

배는 과즙이 풍부하고 단맛이 뛰어나 우리나라에서 가장 즐겨 먹는 과일 중의 하나이다. 현재 국내에서 재배되고 있는 '신고' 품종의 재배면적은 $81.5 \%$ 를 차지하고 있으며 대부분 생과로 소비하고 있다. 이러한 단일 품종의 편중화로 배의 재배 면적 의 $13.3 \%$ 를 신품종으로 갱신하고 있다. 최근 신품종 등 다양 한 배에 대한 소비자의 요구가 커지고 있어 '신고' 품종에 대 한 소비가 현저히 감소하고 있으며 그 수요는 증가하지 않는 실정이다. 이를 극복하기 위해 다양한 신품종 배들이 도입되고 있으며, 이들의 물리적, 화학적 및 생리활성 연구도 활발히 진 행되고 있다. 따라서 본 연구에서는 지금까지 연구해 온 신품 종 배들의 이화학적 및 항산화 활성에 대해 소개하고자 한다.

Keywords 신품종 배 - 이화학적 특성 - 항산화 활성

감사의 글 본 연구는 국립원예특작과학원의 지원 사업비로 이루어진 결과 이며, 이에 감사드립니다(과제번호: PJ01002402).

\section{References}

Ahn ES (2012) Isolation and identification of antioxidants from pear and antioxidant potential of peels and fleshes of pear. Dissertation, Chonnam National University

Cho KS, Kang SS, Cho, HM, Koh GC, Hong KH, Son DS, Kim WC, Kim KY (2003) Breeding of a very soft, juicy, large sized, and high quality mid-season pear cultivar 'Manpungbae'. Korean J Hort Sci Technol 21(1): $25-25$

Choi JH, Kim KY, Lee JC (1988) Effects of pre-pressing condition on quality of pear juice. Korean J Food Sci Technol 30: 827-831

Choi JH (2009) Development of analytical methods of antioxidative polyphenols in Korean Pears and pear products for quality evaluation. Dissertation, Gyeongsang National University

Choi JH, Lee EY, Kim JS, Choi GB, Jung SG, Ham YS, Seo DC, Heo JS (2006) Physiological activities according to cultivars and parts of Ulsan pear. J Korean Soc Appl Biol Chem 49(1): 43-48

Choi JJ, Yim SH, Choi JH, Park JH, Nam SH, Lee HC (2013) Antioxidant activity of Pyrus pyrifolia fruit in different cultivars and parts. Korean $\mathrm{J}$ Food Preserv 20(2): 222-226

Choi OJ, Park HR, Chough SH (1998). Variation of free sugar and amino acid contents of pears during the ripening period. Korean J Soc Food Sci 14(3): $44-48$

Chun JP, Lee UY (2011) Evaluation of quality indices during fruit development and ripening in 'Wonhwang' and 'Whasan'pears. CNU J
Agri Sci 38: 405-411

Harada T, Kurahashi W, Yanai M, Wakasa Y, Satoh T (2005) Involvement of cell proliferation and cell enlargement in increasing the fruit size of Malus species. Sci Hort 105: 447-456

Hong SJ, Kim MS, Park SW, Shin IS (1998) Changes in contents of soluble sugars, organic acids, and the fruit taste of early season pear cultivars during Maturation. Korean J Hort Sci Technol 39(4): 408-411

Hong SS, Hong YP, Im BS, Jeong DS, Shin IS (2004) Influence of picking stage and storage type on the fruit respiration change and panel test in 'Wonhwang' 'Hwasan' and 'Mansoo'pear. Kor J Hort Sci Technol 22: $55-62$

Jiang GH (2015) Physicochemical characteristics of new cultivars of Asian pears and anti-browning effect of ascorbic acid and sodium metabisulfite in pear juice. Dissertation, Chonnam National University

Jiang GH, Kim YM, Nam SH, Yim SH, Eun JB (2016) Enzymatic browning inhibition and antioxidant activity of pear juice from a new cultivar of Asian pear (Pyrus pyrifolia Nakai cv. Sinhwa) with different concentrations of ascorbic acid. Food Sci Biotechnol 25(1): 153-158

Jin YO, Song WS (2012) Antioxidant activity of Pyrus serotina fruit in different cultivars and parts. Korean J Plant Res 25(4): 498-503

Kang SS, Choi JH, Kim YK, Won KH, Won SY, Jo JH, Na YK, Jo JH (2011) Development of stategies to distribute new pear cultivars in to pear orchard. Final report of KOSEF, RDA (Hort.), Suwon

Kang SS, Kim YK, Cho KS, Won KH, Kim MS, Choi JJ, Shin IS, Hwang HS, Lee HC (2012) Breeding of early-season pear cultivar 'Joyskin' for eatable with fruit skin. Korean J Hort Sci Technol 30 (SUPPL. • ×) 140 141.

Kang SS, Kim YK, Won KH, Choi JH, Yim SH, Lee JJ, Cho JK, Na YK, Cho JW (2014) Distribute the superior new pear cultivars into pear orchard for a high quality product. Final report of KOSEF, RDA (Hort.), Suwon

Kim JC, Go GC, Kim KR, Lee JC (1997). Introduction of fruit tree horticulture. Hyangmoonsa, Seoul

Kim JH (2002) Recent pear cultivation. Osung books, Seoul

Kim SB (1988) Studies on the pathogenic fungus, chemical control and resistance of apple rot disease caused by Botryosphaeria dothidea. Dissertation, Wonkwang University

Kim SJ, Choi JJ, Choi JH, Yim SH, Kwon YH, Kim YK, Won KH (2015) Development of practical cultivation techniques for expansion of new pear cultivars. Final report of KOSEF, RDA (Hort.), Suwon

Kim WC, Hwang HS, Shin YU, Lee DK, Kang SJ, Shin IS, Cheon BD, Moon JY, Kim JH, Kim SB (1995) Breeding of a new large sized highquality pear cultivar 'Wonwhang'. Rs Rpt RDA (Hort.) 37: 471-477

Kim WC, Hwang HS, Shin YU, Moon JY, Kim JH, Kang SJ (1994) A new late mid-season pear cultivar, 'Whasan' for growing across the country. Res Rpt (Hort.) 36: 469-474

Kim WC, Hwang SS, Shin IS, Shin YU, Lee DK, Kang SJ, Moon JY, Kim JH (2001) Breeding of a new late-season pear cultivar 'Mansoo' with large sized high quality and long storability. Korean J Hort Sci Technol 19(1): 66-70

Kingston CM (1991) Maturity indices for apple and pear. Horticultural Rev 13: $407-432$

Lee DC, Lee HJ, Jung ST, Han KP, Han HY (1983) Special treatise on fruit crops and horticulture. Hyangmunsa, Seoul

Lee DS, Woo SK, Yang CB (1975) Studies on the chemical composition of major fruits in Korea. Korean J Food Sci Technol 4: 123-139

Lee H, Isse T, Kawamoto T, Woo H, Kim AK, Park JY, Yang M (2012) Effects and action mechanisms of pears (Pyruspyrifolia cv. Shingo) on alcohol detoxification. Phytother Res 26: 1753-1758

Lee JS, Seo HH, Yun IG, Choi JJ, Choi JH, Kim JK (2008) Occurrence of skin browning by mechanical injuries on the fruits of 'Mansu' pear. Korean Soc Plant Patho 14(3): 205-209

Lee JW, Kim SH, Hong SI, Jeong MC, Park HW, Kim DM (2003) Quality distribution of Korean Shingo pears. Korean J Food Preserv 10: 162-168 Lee KY, Ko KC, Kim KR, Kim SB, Kim JH, Kim JC, Park DB, Park YB, 
Byun JK, Chim KK, Won SH, Lee DC, Lee HJ, Jung ST, Han KP, Han HY (1983) Special treatise on fruit crops and horticulture. Hyangmunsa, Seoul

Lee UY, Oh KY, Moon SJ, Hwang YS, Chun JP (2012) Effects of 1methylcyclopropene (1-MCP) on fruit quality and occurrence of physiological disorders of Asian pear (Pyrus pyrifolia), 'Wonhwang' and 'Whasan', during shelf-life. Kor J Hort Sci Technol 30: 534-542

Machida Y (1965) Studies on texture of pear fruit. 1. Textureof canned Bartlett pears processed from raw materials obtained from different region. Part 2. Cell-wall substances of parenchymacells. Rept Hiratzuka Hort Sta A-4: 107-124

Park DM, Kim WS, and Kim HC (1984) The fruit growth curves and changes in carbohydrates of the fruit of four pear cultivars (Pyrus pyrifolia). Korean J Hort Sci Technol 25(1): 45-49

Park HW, Park JD, Kim DM, and Lee MH (1988) Freshness extension of 'Shingo' pear packed with expandable polystyrene form box. J Kopast 4(1): 12-17

Park JE, Kwon YH, Lee BHN, Park YS, Jung MH, Choi JH, Park HS (2013) Korean J Hort Sci Technol 31(4): 407-414

Park YO, Choi JJ, Choi JH, Kim MS, Yim SH, Lee HC (2012) Antioxidant activities of young and mature fruit in three Asian pear cultivars. Korean
J Hort Sci Technol 30(2): 208-213

RDA (2003) Anniversary of fifty year in Horticulture Research Institute. Scientific Horticulture, Seoul

Ryugo K (1969) Seasonal trends of titratable acids, tannins andpoly phenolic compounds and cell wall constituents in orientalpear fruit (Pyrus serotina, Rehd). J Agr Food Chem 17: 43-47

Seo MS (2014) Changes of total phenolic compounds and antioxidant capacity of pear fruits and leaves at growth stages. Dissertation, Chonnam National University

Son DS, Kang SJ, Jeong SB, Kim JK, Cho KS, Choi YM, Hong KJ, Choi JJ, Kang SS (2004) Phytochemical and health effect of pear. RDA Semyung, Suwon

Wilkinson BG (1970) Physiological disorders of fruit after harvesting. In: A.C. Hulme (ed). The biochemistryof fruit and products. Academic, New York

Yu TJ (1989) The food guide. Munundang, Seoul

Zhang YB, Choi HJ, Han HS, Park JH, Son JH, Bae JH (2003) Chemical structure of polyphenol isolated from Korean pear (pyrus pyrifolia Nakai). Korean J Food Sci Technol 35: 959-967

Zhang X (2007) Changes of phenolic compounds and pectin in Asian pear fruit during growth. Korean J Food Sci Technol 35(1): 7-13 